\title{
Labyrinthe
}

$11 \mid 2002$

Numéro 11

\section{Les mises à mort dans Rome, ville ouverte de Roberto Rossellini}

\section{Emmanuel Taïeb}

\section{(2) OpenEdition \\ 12 Journals}

\section{Electronic version}

URL: http://journals.openedition.org/labyrinthe/659

DOI: 10.4000/labyrinthe.659

ISSN: 1950-6031

\section{Publisher}

Hermann

\section{Printed version}

Date of publication: 14 January 2002

Number of pages: $67-77$

\section{Electronic reference}

Emmanuel Taïeb, "Les mises à mort dans Rome, ville ouverte de Roberto Rossellini », Labyrinthe [Online], 11 | 2002, Online since 15 April 2005, connection on 09 May 2019. URL : http://

journals.openedition.org/labyrinthe/659; DOI : 10.4000/labyrinthe.659

This text was automatically generated on 9 May 2019.

Propriété intellectuelle 


\title{
Les mises à mort dans Rome, ville ouverte de Roberto Rossellini
}

\author{
Emmanuel Taïeb
}

